\title{
Bioaccumulation of Heavy Metals in Clarias gariepinus and Oreochromis spirulus niger from Masinga Reservoir, Kenya
}

\author{
Nzeve, J. K* ., Njuguna, S. G. and Kitur, E. C. \\ Department of Environmental Sciences, Kenyatta University, P.O.Box 43844 - 00100, Nairobi, Kenya
}

\begin{abstract}
The pollution of aquatic ecosystems with heavy metals has become a worldwide concern. This is because of their ability to bioaccumulate in aquatic organisms and especially in fish which is a source of livelihood for human populations. Therefore, an assessment of heavy metal contamination ( $\mathrm{Cu}, \mathrm{Zn}, \mathrm{Pb}, \mathrm{Cr}$ and $\mathrm{Mn}$ ) in two selected food fish species, Clarias gariepinus and Oreochromis spirulus niger in Masinga reservoir was carried out between January 2013 and December 2013. Heavy metal Concentrations were determined using atomic absorption spectrophotometer. The data obtained was analyzed using one way analysis of variance and significant differences accepted at $p \leq 0.05$. Post Hoc Turkeys' test was used to separate means. In Clarias gariepinus, mean metal concentrations ( $\mathrm{mg} / \mathrm{kg}$ ) in muscles were $\mathrm{Cu}(0.677-0.974)$, Zn (32.929 - 37.205), Pb (0.643 - 1.078), $\mathrm{Cr}(0.516-0.858)$ and $\mathrm{Mn}(0.452-0.990)$. Pb exhibited a significance difference between the sites $(p<0.05)$. Mean values for heavy metals in Oreochromis spirulus niger $(\mathrm{mg} / \mathrm{kg})$ for different sites were $\mathrm{Cu}$ (0.515 - 0.782), Zn (29.645 - 37.999), Pb (0.552 - 0.765), Cr (0.559-0.791) and Mn (0.183 - 1.480). Only Mn showed significant differences between the sites $(p<0.05)$. Heavy metal concentrations in the two fish species were lower than World Health Organization (WHO) set limit except for Cr. Results from this study demonstrate the need for an ecosystem approach towards sustainable management of reservoirs. This will curb aquatic pollution which is a health risk for people consuming aquatic resources contaminated with heavy metals.
\end{abstract}

Key Words: Heavy metals, Bioaccumulation, pollution, fish, Masinga reservoir.

\section{Introduction}

The global consumption of fish and derived fish products has generally increased during recent decades [1]. Fish provide high quality animal protein, vitamins, minerals and omega-3 fatty acids which have been associated with health benefits due to their cardio-protective effects [1], [2]). Despite the benefits, there are health risks related to fish consumption, mainly due to potential adverse effects of heavy metal contamination. Heavy metals are well known environmental pollutants that cause serious health hazards to human beings [3]. Anthropogenic activities continuously increase the amount of heavy metals in the environment, especially in aquatic ecosystems. Increase in population, urbanization, industrialization and agricultural practices as well as lack of environmental regulations have further aggravated the situation [4]. As the metal levels increase in aquatic ecosystems, they raise the concern of metal bioaccumulation through the food chain and related human health hazards [5], [6], [7]. Heavy metal contamination in aquatic ecosystems can be expressed by its high concentration in water, as well as in sediments and aquatic organisms [8]. Fish assimilate metals by ingestion of particulate materials suspended in water, ingestion of food, ion exchange of dissolved metals across lipophilic membranes for example the gills, and adsorption on tissue and membrane surfaces [9].

Monitoring of heavy metal pollution in Kenya is a priority area of research since metal concentrations in aquatic ecosystems affect the fish industry which is a major source of livelihood [10]. Most of the research done in Kenya on heavy metal contaminants has concentrated on natural lakes and along the coast-line [11], [12], [13], [14], [15], [16] and [17]. There is very little research on heavy metal pollution that has been done on reservoirs in Kenya and especially the ones with fisheries of economic value like Masinga. Consequently, there is a limited understanding of the human health risks associated with consumption of fish from the reservoir. This study focused on assessing the heavy metals concentrations in muscle tissues of two main food fish species Tilapia (Oreochromis spirulus niger) and African Catfish (Clarias gariepinus) from Masinga reservoir.

\section{Materials and Methods}

\subsection{Study Area}

The study was carried out in Masinga reservoir which lies between latitude $\left(0^{0} 45^{\prime} \mathrm{S} ; 1^{0} 11^{\prime} \mathrm{S}\right)$ and longitude $\left(37^{\circ} 0^{\prime} \mathrm{E} ; 37^{\circ} 46^{\prime} \mathrm{E}\right)$ at an altitude of $1056.5 \mathrm{~m}$ above sea level. It is the upper most cascade dam of the seven forks development scheme on the Tana River. It is a multi-branched type of reservoir with a large number of shallow bays and a high shore line surface area ratio. The dam has a full operation surface area of $125 \mathrm{~km}^{2}$ and extends $45 \mathrm{~km}$ upstream along the Tana River (Figure 1). The mean depth is $13.8 \mathrm{~m}$ while the maximum depth at the dam wall is $48 \mathrm{~m}$ [18]. Masinga dam has a catchment area of $7,355 \mathrm{~km}^{2}$ and creates the largest storage and regulatory structure on the Tana River for regulating flows for downstream hydroelectric power dams. The 
reservoir is a source of livelihood to rural populations who live nearby especially from Machakos, Embu and Murang'a counties.

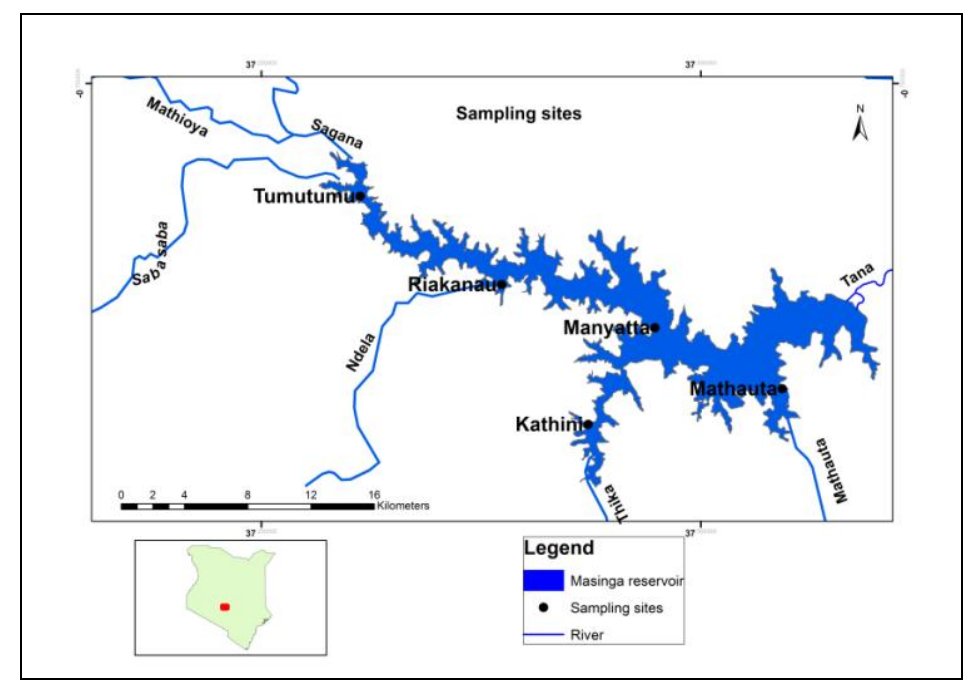

Figure 1: A map of Masinga reservoir showing the five sampling sites

\subsection{Sampling and Frequency}

Five sampling sites were chosen to represent different sub basins that drain into the reservoir in order to understand the influence of natural and human activities on the reservoir. The geographical location of each selected sampling site within the reservoir is shown in Table 1. Sampling was carried out once a month for one year (January 2013 - December 2013) in all the sampling stations in reservoir.

\subsection{Sampling of Fish and Storage}

Oreochromis spirulus niger samples were caught using gill nets while Clarias gariepinus were obtained from all five sampling sites by use of hook and long lines that had been cast and left overnight. A total of 157 Tilapia and 164 African Catfish samples were caught during the study period. Fish samples obtained were immediately kept in pre-cleaned polythene bags, sealed, labeled and kept in ice boxes for transportation to the laboratory at Kenyatta University. In the laboratory, total length $(\mathrm{cm})$ and weight (grams) were recorded. The fish samples were then kept in a deeper freezer until muscle tissues were extracted for analysis.

Table 1: Geographical coordinates and water depth of sampling sites in Masinga reservoir

\begin{tabular}{|l|l|l|l|}
\hline Sampling Site & Latitude & Longitude & Depth $(\mathbf{m})$ \\
\hline Kathini (S1) & $00^{0} 94322 \mathrm{~S}$ & $037^{0} 43237 \mathrm{E}$ & $10.33 \pm 0.99$ \\
\hline Mathauta (S2) & $00^{0} 92571 \mathrm{~S}$ & $037^{0} 54548 \mathrm{E}$ & $22.42 \pm 2.50$ \\
\hline Manyatta (S3) & $00^{0} 88736 \mathrm{~S}$ & $037^{0} 47279 \mathrm{E}$ & $21.00 \pm 6.70$ \\
\hline Riakanau (S4) & $00^{0} 86476 \mathrm{~S}$ & $037^{0} 38770 \mathrm{E}$ & $7.25 \pm 1.14$ \\
\hline Tumutumu (S5) & $00^{0} 81416 \mathrm{~S}$ & $037^{0} 30621 \mathrm{E}$ & $7.58 \pm 2.02$ \\
\hline
\end{tabular}

\subsection{Processing and Digestion of Fish Tissues for Metal Analysis}

The deep frozen fish samples, Oreochromis spirulus niger and Clarias gariepinus were thawed at ambient laboratory temperature overnight. The skin of each fish sample was removed using plastic knives to avoid metal contamination and this was followed by extraction of fish muscles. Fish muscles were put in a preacid washed and oven-dried crucibles and then dried to a constant weight in an oven at $50^{\circ} \mathrm{C}$. The dried fish samples were cooled in desiccators at room temperature. After cooling, $2 \mathrm{~g}$ of fish muscles was accurately weighed using a Shimadzu electronic weighing balance (Model ATX224) and transferred into a clean beaker. Dried fish samples for each fish species were digested in triplicates according to method described in [19]. To each weighed fish muscle, $18 \mathrm{ml}$ of concentrated nitric acid was added and heated at $100{ }^{\circ} \mathrm{C}$ on a hot plate in a fume hood chamber. A few drops of hydrogen peroxide (analytical grade) were added until there were no brown fumes. The digested fish samples solution was cooled and filtered using Whatman No.42 filter paper into a 25 $\mathrm{ml}$ volumetric flask and topped to the mark with distilled water. Heavy metal analysis was done using a computerized Varian Atomic Absorption Spectrophotometer (model Spectra AA-10). Blank solutions were prepared similarly. 


\section{Bioaccumulation of Heavy Metals in Clarias gariepinus and Oreochromis spirulus niger from}

Masinga Reservoir, Kenya

\subsection{Statistical Data Analysis}

Data analysis was done using a computerized statistical programme (STATISTICA 8.0, 2007). The data were subjected to one way analysis of variance (ANOVA) and significant differences accepted at $\mathrm{p} \leq 0.05$ [20]. Where significant differences were found, the mean values were separated using post-hoc Tukey's (HSD) test. Descriptive statistics for all collected data were also obtained using STATISTICA software.

\section{Results and Discussions}

The mean heavy metal concentrations in muscle tissues of Clarias gariepinus and Oreochromis spirulus niger are presented in Tables 2 and 3 respectively. There were no significant variations ( $p>0.05)$ in $\mathrm{Cu}, \mathrm{Zn}, \mathrm{Cr}$ and $\mathrm{Mn}$ concentrations observed in Catfish muscles. However, $\mathrm{Pb}$ levels in catfish muscles exhibited significant differences $(\mathrm{p}<0.05)$ between sampling sites. Mn concentrations in tilapia tissue muscles had significant differences $(p<0.05)$ between sampling sites but no significant variations $(p>0.05)$ were noted for the other elements studied.

In this study, $\mathrm{Cu}$ levels recorded varied with fish species and different sampling sites. Heavy metal concentrations in the tissue of fresh water fish varies due to differences in metal concentrations and chemical characteristics of water from which fish are sampled, their ecological needs; metabolism and feeding habits [21]. Mean $\mathrm{Cu}$ levels for Catfish ranged from $0.677 \pm 0.465 \mathrm{mg} / \mathrm{kg}$ (Manyatta) to $0.974 \pm 1.284 \mathrm{mg} / \mathrm{kg}$ (Riakanau). Tilapia had the highest $\mathrm{Cu}$ levels at Kathini $(0.782 \pm 0.327 \mathrm{mg} / \mathrm{kg})$ while the lowest levels were found at Mathauta $(0.515 \pm 0.367 \mathrm{mg} / \mathrm{kg})$. African catfish is omnivorous and preys on small fish of other species. This could have led to high $\mathrm{Cu}$ levels in Catfish as compared to tilapia which feeds on phytoplankton. Cu levels found in Oreochromis spirulus niger were higher than mean $\mathrm{Cu}$ values of $0.045 \mathrm{mg} / \mathrm{kg}$ recorded in muscle tissues of tilapia fish from Tono irrigation reservoir in Ghana [22] but lower than $2.8-48.84 \mathrm{mg} / \mathrm{kg}$ observed in tilapia (Oreochromis niloticus) of Northern delta lakes, Egypt [23]. The mean $\mathrm{Cu}$ concentrations recorded in this study compared well with $0.85 \mathrm{mg} / \mathrm{kg}$ in Tilapia muscles from Lake Hashenge in Ethiopia [24]. Cu levels in Catfish muscles obtained were lower than $1.01-5.48 \mathrm{mg} / \mathrm{kg}$ recorded in same fish species from River Nile, Egypt [25]. Studies carried out [26] at Nsawam in Densu River, Ghana found very high mean Cu levels in African catfish $(45.60 \pm 0.74 \mathrm{mg} / \mathrm{kg})$ and Tilapia zilli $(91.08 \pm 1.04 \mathrm{mg} / \mathrm{kg})$. The Cu concentration levels recorded in muscles of the two selected fish species were below the WHO recommended limit of $3.0 \mathrm{mg} / \mathrm{kg}$ in fish and fish products [27].

The main source of $\mathrm{Zn}$ pollution in aquatic environment is from fertilizers, sewage sludge, industrial wastes and mining [28]. The highest mean $\mathrm{Zn}$ concentration in African Catfish muscles was observed at Riakanau $(38.396 \pm 19.892 \mathrm{mg} / \mathrm{kg})$ and the lowest at Tumutumu $(32.929 \pm 18.278 \mathrm{mg} / \mathrm{kg}) . \mathrm{Zn}$ concentrations in tilapia muscles were lowest at Kathini $(29.645 \pm 5.302 \mathrm{mg} / \mathrm{kg})$, and highest at Mathauta $(37.999 \pm 9.692 \mathrm{mg} / \mathrm{kg})$. The sources of $\mathrm{Zn}$ in the study may be attributed to use of chemical fertilizers, sewage sludge and industrial wastes from the catchment. Compared to mean $\mathrm{Zn}$ concentrations recorded in similar fish species from other aquatic ecosystems, slightly higher levels $(11.62-71.85 \mathrm{mg} / \mathrm{kg})$ in African Catfish muscles have been recorded in River Nile, Egypt [25] while [22] obtained lower mean Zn levels $(0.004 \mathrm{mg} / \mathrm{kg})$ in tilapia caught from Tono irrigation reservoir in Ghana. Studies carried out in Lake Hashenge, Ethiopia revealed comparable Zn levels in Tilapia (24.95 $\pm 1.80 \mathrm{mg} / \mathrm{kg})$ muscles [24]. Zn concentration levels in Tilapia fish from Masinga reservoir were also lower than $28.00-76.33 \mathrm{mg} / \mathrm{kg}$ found in Athi river system, Kenya [29]. In Afikpo freshwater ecosystem in Nigeria, lower mean $\mathrm{Zn}$ levels in Tilapia zilli have been recorded [30]. Zn levels recorded during this study in the two food fish species were below the $75 \mathrm{mg} / \mathrm{kg}$ recommended limit for $\mathrm{Zn}$ in fish and fish products [31].

$\mathrm{Pb}$ is a non essential element and higher concentrations in aquatic organisms may be due to discharge of industrial, sewage and agricultural wastes into aquatic environment [25]. Tumutumu had the highest mean $\mathrm{Pb}$ levels $(1.078 \pm 0.353 \mathrm{mg} / \mathrm{kg})$ in Catfish muscles and the lowest levels were at Kathini $(0.643 \pm 0.253 \mathrm{mg} / \mathrm{kg}) . \mathrm{Pb}$ levels in Catfish muscles from Tumutumu and Manyatta were significantly different $(p<0.05)$ from levels recorded in the other sampling sites (Table 1). Mean $\mathrm{Pb}$ concentration levels found in Tilapia muscles ranged from $0.552 \pm 0.404 \mathrm{mg} / \mathrm{kg}$ (Tumutumu) to $0.765 \pm 0.413 \mathrm{mg} / \mathrm{kg}$ at Kathini. Mathauta and Manyatta had $0.684 \pm$ $0.315 \mathrm{mg} / \mathrm{kg}$ and $0.609 \pm 0.353 \mathrm{mg} / \mathrm{kg}$ respectively. African Catfish had higher Pb levels compared to Tilapia which could be attributed to their different feeding habits. $\mathrm{Pb}$ concentrations recorded in the two fish species during this study were lower than the WHO recommended limit of $2.0 \mathrm{mg} / \mathrm{kg}$ for $\mathrm{Pb}$ in fish and fish products [27]. This study showed lower Pb levels compared to results observed in African Catfish in Lake Victoria [32] and $5.895-14.51 \mathrm{mg} / \mathrm{kg}$ in River Nile, Egypt [25]. However, [26] recorded much lower mean $\mathrm{Pb}$ levels in African Catfish muscles $(0.08 \pm 0.01 \mathrm{mg} / \mathrm{kg})$ and Tilapia zilli $(0.34 \pm 0.02 \mathrm{mg} / \mathrm{kg})$ from Densu River, Ghana.

$\mathrm{Cr}$ and its compounds are known to cause cancer of the lung, nasal cavity and suspected to cause cancer of the stomach and larynx [33].The main sources of $\mathrm{Cr}$ are industrial wastes such as $\mathrm{Cr}$ pigment, tannery wastes, leather manufacturing wastes and municipal sewage sludge [34], [35]. In this study, African Catfish muscles had mean $\mathrm{Cr}$ concentrations ranging from $0.566 \pm 0.233 \mathrm{mg} / \mathrm{kg}$ (Tumutumu) to $0.858 \pm 0.459 \mathrm{mg} / \mathrm{kg}$ 


\section{Bioaccumulation of Heavy Metals in Clarias gariepinus and Oreochromis spirulus niger from Masinga Reservoir, Kenya}

(Mathauta). Mean $\mathrm{Cr}$ concentrations in Tilapia muscles ranged from $0.541 \pm 0.304 \mathrm{mg} / \mathrm{kg}$ (Riakanau) to $0.791 \pm$ $0.402 \mathrm{mg} / \mathrm{kg}$ (Manyatta). This was higher than $0.37 \pm 0.14 \mathrm{mg} / \mathrm{kg}$ in Oreochromis niloticus muscles sampled from Hashenge Lake, Ethiopia [24] but comparable to $0.56 \mathrm{mg} / \mathrm{kg}$ in muscles of Oreochromis niloticus obtained from river Usuma, Nigeria [36]. However, mean $\mathrm{Cr}$ concentrations obtained in this study were lower compared to $2.37-5.47 \mathrm{mg} / \mathrm{kg}$ in African Catfish muscles sampled from River Nile [25]. This study found higher $\mathrm{Cr}$ concentrations in both Catfish and tilapia than the recommended limit of $0.15 \mathrm{mg} / \mathrm{kg}$ chromium in fish and fish products [37]. The elevated Cr levels could be attributed to municipal and tannery wastes from the towns located in the upper Masinga reservoir catchment.

Table 2: Mean \pm Standard deviation and range for heavy metal concentrations in African Catfish during the study period. Means in same row with different superscripts are significantly different at $p<0.05$ levels.

\begin{tabular}{|c|c|c|c|c|c|}
\hline Element/Site & Kathini & Mathauta & Manyatta & Riakanau & Tumutumu \\
\hline $\begin{array}{l}\mathrm{Cu}(\mathrm{mg} / \mathrm{kg}) \\
\text { Range }\end{array}$ & $\begin{array}{c}0.896 \pm 0.868^{\mathrm{a}} \\
0.28-2.48\end{array}$ & $\begin{array}{c}0.949 \pm 0.697^{\mathrm{a}} \\
0.26-1.95\end{array}$ & $\begin{array}{c}0.677 \pm 0.465^{\mathrm{a}} \\
0.20-1.73\end{array}$ & $\begin{array}{c}0.974 \pm 1.284^{\mathrm{a}} \\
0.33-2.30\end{array}$ & $\begin{array}{c}0.791 \pm 0.855^{\mathrm{a}} \\
0.23-2.04\end{array}$ \\
\hline $\begin{array}{l}\mathrm{Zn}(\mathrm{mg} / \mathrm{kg}) \\
\text { Range }\end{array}$ & $\begin{array}{c}33.999 \pm 8.685^{\mathrm{a}} \\
21.34-53.00 \\
\end{array}$ & $\begin{array}{c}33.070 \pm 16.072^{\mathrm{a}} \\
20.96-55.00\end{array}$ & $\begin{array}{c}37.205 \pm 12.414^{\mathrm{a}} \\
23.90-57.00\end{array}$ & $\begin{array}{c}38.396 \pm 19.892^{\mathrm{a}} \\
27.63-59.50\end{array}$ & $\begin{array}{c}32.929 \pm 18.279^{\mathrm{a}} \\
17.06-61.00\end{array}$ \\
\hline $\begin{array}{l}\mathrm{Pb}(\mathrm{mg} / \mathrm{kg}) \\
\text { Range }\end{array}$ & $\begin{array}{c}0.643 \pm 0.253^{\mathrm{a}} \\
0.48-1.00 \\
\end{array}$ & $\begin{array}{c}0.864 \pm 0.314^{\mathrm{a}} \\
0.44-1.56 \\
\end{array}$ & $\begin{array}{c}1.057 \pm 0.494^{\mathrm{b}} \\
0.54-1.92 \\
\end{array}$ & $\begin{array}{c}0.963 \pm 0.309^{\mathrm{a}} \\
0.58-1.47 \\
\end{array}$ & $\begin{array}{c}1.078 \pm 0.353^{\mathrm{b}} \\
0.28-1.56 \\
\end{array}$ \\
\hline $\begin{array}{l}\mathrm{Cr}(\mathrm{mg} / \mathrm{kg}) \\
\text { Range }\end{array}$ & $\begin{array}{c}0.848 \pm 0.460^{\mathrm{a}} \\
0.40-1.56\end{array}$ & $\begin{array}{c}0.858 \pm 0.459^{\mathrm{a}} \\
0.20-1.65\end{array}$ & $\begin{array}{c}0.760 \pm 0.233^{\mathrm{a}} \\
0.26-1.11 \\
\end{array}$ & $\begin{array}{c}0.791 \pm 0.586^{\mathrm{a}} \\
0.50-1.23 \\
\end{array}$ & $\begin{array}{c}0.566 \pm 0.233^{\mathrm{a}} \\
0.20-1.05 \\
\end{array}$ \\
\hline $\begin{array}{l}\text { Mn (mg/kg) } \\
\text { Range }\end{array}$ & $\begin{array}{c}0.452 \pm 0.368^{\mathrm{a}} \\
0.08-1.00\end{array}$ & $\begin{array}{c}0.525 \pm 0.671^{\mathrm{a}} \\
0.19-1.05\end{array}$ & $\begin{array}{c}0.777 \pm 0.737^{\mathrm{a}} \\
0.35-1.13\end{array}$ & $\begin{array}{c}0.485 \pm 0.269^{\mathrm{a}} \\
0.10-0.79\end{array}$ & $\begin{array}{c}0.990 \pm 0.984^{\mathrm{a}} \\
0.10-1.66\end{array}$ \\
\hline
\end{tabular}

$\mathrm{Mn}$ is one of the commonly found elements in the lithosphere. It is an essential micro nutrient and functions as a co-factor for many enzyme activities [38]. However, high Mn concentration interferes with central nervous system of invertebrates and hence a matter of concern as the consumption of Mn contaminated fish could result to Mn related disorders in the consumers [39]. The Mn concentration levels in the two fish species during the study did not exceed the WHO limit of $2.50 \mathrm{mg} / \mathrm{kg}$ for fish and fish products [40]. The highest Mn concentration in African Catfish was at Tumutumu $(0.990 \pm 0.984 \mathrm{mg} / \mathrm{kg})$ followed by Manyatta $(0.777 \pm 0.737 \mathrm{mg} / \mathrm{kg})$ and the lowest level $(0.452 \pm 0.368 \mathrm{mg} / \mathrm{kg})$ was at Kathini. Mathauta and Riakanau had mean Mn levels of $0.525 \pm 0.671 \mathrm{mg} / \mathrm{kg}$ and $0.485 \pm 0.269 \mathrm{mg} / \mathrm{kg}$ respectively. There was no significant difference $(\mathrm{p}>0.05)$ in Mn Concentration levels in Catfish between the sampling sites. Mean Mn concentrations in Tilapia muscles significantly varied between sites ( $\mathrm{p}<0.05$ ) and ranged from $0.183 \pm 0.290 \mathrm{mg} / \mathrm{kg}$ (Mathauta) to $1.480 \pm 0.312 \mathrm{mg} / \mathrm{kg}$ (Tumutumu). Mean Mn concentration levels observed in other sampling sites were $0.518 \pm 0.303 \mathrm{mg} / \mathrm{kg}$ (Kathini), $0.217 \pm$ $0.377 \mathrm{mg} / \mathrm{kg}$ (Manyatta) and $0.409 \pm 0.414 \mathrm{mg} / \mathrm{kg}$ (Riakanau). Mn concentration levels recorded in this study were lower compared to mean Mn levels in muscles of Tilapia Oreochromis niloticus $(1.01 \pm 0.32 \mathrm{mg} / \mathrm{kg})$ sampled from Hashenge Lake, Ethiopia [24]. It was also, lower compared to $1.74 \mathrm{mg} / \mathrm{kg}$ in Tilapia from Densu River, Ghana [41] and $1.18 \mathrm{mg} / \mathrm{kg}$ in Tilapia zilli sampled from River Benue, Nigeria [42]. However, the concentrations compared well with Mn levels $0.78 \mathrm{mg} / \mathrm{kg}$ and $0.607 \mathrm{mg} / \mathrm{kg}$ in muscles of Clarias gariepinus from Densu River, Ghana [41] and River Benue, Nigeria [42] respectively.

Table 3: Mean \pm Standard deviation and range for heavy metal concentrations in Tilapia during the study period. Means in same row with different superscripts are significantly different at $\mathrm{p}<0.05$ levels. ND - Below detectable limit

\begin{tabular}{|l|c|c|c|c|c|}
\hline Element/ Site & Kathini & Mathauta & Manyatta & Riakanau & Tumutumu \\
\hline $\mathrm{Cu}(\mathrm{mg} / \mathrm{kg})$ & $0.782 \pm 0.327^{\mathrm{a}}$ & $0.515 \pm 0.367^{\mathrm{a}}$ & $0.709 \pm 0.352^{\mathrm{a}}$ & $0.640 \pm 0.309^{\mathrm{a}}$ & $0.717 \pm 0.366^{\mathrm{a}}$ \\
Range & $0.34-1.18$ & $0.10-1.31$ & $0.13-1.40$ & $0.20-1.30$ & $0.11-1.25$ \\
\hline $\mathrm{Zn}(\mathrm{mg} / \mathrm{kg})$ & $29.645 \pm 5.302^{\mathrm{a}}$ & $37.999 \pm 9.692^{\mathrm{a}}$ & $33.177 \pm 10.562^{\mathrm{a}}$ & $37.258 \pm 9.843^{\mathrm{a}}$ & $35.714 \pm 9.580^{\mathrm{a}}$ \\
Range & $25.50-41.90$ & $24.00-57.50$ & $18.69-54.33$ & $21.95-55.90$ & $17.50-54.63$ \\
\hline $\mathrm{Pb}(\mathrm{mg} / \mathrm{kg})$ & $0.765 \pm 0.413^{\mathrm{a}}$ & $0.684 \pm 0.315^{\mathrm{a}}$ & $0.609 \pm 0.353^{\mathrm{a}}$ & $0.650 \pm 0.228^{\mathrm{a}}$ & $0.552 \pm 0.404^{\mathrm{a}}$ \\
Range & $0.21-1.57$ & $0.25-1.31$ & $\mathrm{ND}-1.07$ & $0.32-1.03$ & $\mathrm{ND}^{\mathrm{a}}-1.08$ \\
\hline $\mathrm{Cr}(\mathrm{mg} / \mathrm{kg})$ & $0.559 \pm 0.222^{\mathrm{a}}$ & $0.679 \pm 0.315^{\mathrm{a}}$ & $0.791 \pm 0.402^{\mathrm{a}}$ & $0.541 \pm 0.304^{\mathrm{a}}$ & $0.652 \pm 0.521^{\mathrm{a}}$ \\
$\mathrm{Range}$ & $0.20-0.85$ & $0.41-1.23$ & $0.40-1.15$ & $0.16-1.00$ & $0.43-1.02$ \\
\hline Mn $(\mathrm{mg} / \mathrm{kg})$ & $0.518 \pm 0.303^{\mathrm{a}}$ & $0.183 \pm 0.290^{\mathrm{a}}$ & $0.217 \pm 0.377^{\mathrm{a}}$ & $0.409 \pm 0.414^{\mathrm{a}}$ & $1.480 \pm 0.312^{\mathrm{b}}$ \\
Range & $0.23-0.90$ & $\mathrm{ND}-0.74$ & $\mathrm{ND}-0.96$ & $0.16-1.00$ & $0.96-1.78$ \\
\hline
\end{tabular}

\section{Conclusions and Recommendations}

The concentrations of $\mathrm{Cu}, \mathrm{Zn}, \mathrm{Pb}$, and $\mathrm{Mn}$ in muscle tissues of Clarias gariepinus and Oreochromis spirulus niger were below the WHO recommended limit for fish and fish products. Hence, it was concluded that these metals have no immediate threat on the health of consumers of fish and fish products from Masinga reservoir. However, the levels of $\mathrm{Cr}$ in the muscle tissues of the two fish species exceeded the WHO limits for 


\section{Bioaccumulation of Heavy Metals in Clarias gariepinus and Oreochromis spirulus niger from Masinga Reservoir, Kenya}

$\mathrm{Cr}$ in fish and fish products. This exposes the consumers of fish and fish products from Masinga reservoir to health risks. The elevated $\mathrm{Cr}$ concentrations in the two fish species is a sign of untreated or inadequately treated wastewater from tanneries located in the catchment. Therefore, wastewaters emanating from the tanning process should be adequately treated to meet the minimum set standards before being released into the aquatic environment.

\section{Acknowledgements}

The authors wish to thank National Commission for Science, Technology and Innovation (NACOSTI), Kenya, for funding the study. We are also grateful to department of Chemistry, Kenyatta University and Department of Mines and Geology, Nairobi, for permitting us to carry out sample analysis in their laboratories.

\section{References}

[1]. Wim, V., Issabelle, S., Karen Stefan, D. H. and John, V. C. (2007). Consumer perception versus scientific evidence of farmed and wild fish: exploratory insights for Belgium. Aquaculture International 15: 121-136

[2]. Gamal, E.D and Shamery, M.R. (2010). Studies of contamination and quality of fresh fish meat during storage. Egyptian Academic Journal of Biological Science, 2:65-74

[3]. Jarup, L. (2003). Hazards of heavy metal contamination. Br.Med.Bull.68: 167-182

[4]. Gupta A., Rai D. K., Pandey R. S. and Sharma B. (2009). Analysis of some heavy metals in the riverine water, sediments and fish from river Ganges at Allahabad. Environ. Moni. Assess.157:449-458

[5]. Wright D.A. and Welbourn P. (2002). Environmental Toxicology, Cambridge Press, Cambridge

[6]. Indrajith, H.A.P., Pathiratne, K.A.S. and Pathiratne, A. (2008). Heavy metal levels in two fish species from Ngembo estuary, Sri Lanka: Relationships with the body size. Sri Lanka J. Aquat. Sci. 13 (2008): 63-81

[7]. Agah H., Leermakers M., Elskens M., Fatemi S. M.R. and Baeyens W. (2009). Accumulation of trace metals in the muscles and liver of five fish species from the Persian Gulf. Environ. Monit. Assess. 157: 499-514

[8]. Pham, Nga Thi Thu., Pulkownik, A. and Buckney, R.T. (2007). Assessment of heavy metals in sediments and aquatic organisms in West Lake (Ho Tay), Hanoi, Vietnam. Lakes \& Reservoirs: Research and Management 2007: 12: 285 - 294

[9]. Allinson, G., Salzman,S.A., Turoczy,N., Nishikawa, M., Amarasinghe, U.S., Nirbadha, K.G.S and Silva, De. S.S. (2009). Trace Metal Concentrations in Nile Tilapia (Oreochromis niloticus) in Three Catchments, Sri Lanka. Bull. Environ. Contam. Toxicol.(2009). 82: $389-394$

[10]. Ochieng, E. Z., Lalah, J.O. and Wandiga, S.O. (2008). Water quality and trace metal distribution in a pristine lake in the lake Basin in Kenya. Bull. Environ. Contam. Toxicol. (2008) 80: $362-366$

[11]. Okoth,O.E., Wim,A., Osano,O., Kraak,M.H.S., Ngure,V., Makwali,J. and Orina,S.P. (2010). Use of the fish endoparasite Ligula intestinalis (L. 1758) in an intermediate cyprinid host (Rastreneobola argentea) for biomonitoring heavy metal contamination in Lake Victoria, Kenya. Lakes and Reservoirs: Research and Management 2010 15: 63-73

[12]. Mwamburi, J. (2009). Trace metal concentration in water and sediments of satellite lakes within Lake Victoria (Kenya) basin. Lakes and Reservoirs: Research and Management 2009 14: 203-219

[13]. Lalah, J.O., Ochieng, E. Z. and Wandiga, S.O. (2008).Sources of heavy metal input into Winam Gulf, Kenya.. Bull. Environ. Contam. Toxicol. (2008) 81: $277-284$

[14]. Ochieng, E. Z., Lalah, J.O and Wandiga, S.O. (2007). Analysis of heavy metals in water and surface sediments in five Rift Valley lakes in Kenya for assessment of recent increase in anthropogenic activities. Bull. Environ. Contam. Toxicol. (2007) 79: 570 -576

[15]. Kamau, N.J., Gachanja, A., Ngila, C., Kazungu,M.J and Gatagwu,J. (2007). Seasonal and spatial variations of labile copper, iron, manganese, lead and zinc sediment fractions in Lake Naivasha, Kenya. Lakes and Reservoirs: Research and Management 2007 12: 303-313

[16]. Mwashote, B.M. (2003). Levels of cadmium and lead in water, sediments and selected fish species in Mombasa, Kenya. Western Indian Ocean J. Mar. Sci. Vol. 2No. 1 pp. 25 - 34, 2003

[17]. Kamau,J.N. (2002). Heavy metal distributions and environment at Port-Reitz creek, Mombasa. Western Indian Ocean J. Mar. Sci. Vol. 1 No. 1 pp. $65-70,2002$

[18]. Jumbe, J.J. (2003). The effects of changing water level, the fishes and fisheries of Masinga and Kamburu Dams, Tana River, Kenya. $\mathrm{PhD}$. Thesis Kenyatta University, Kenya.

[19]. APHA (2005). Standard Methods for the Examination of Water and waste-water $21^{\text {st }}$ Edition. Washington, D. C (2005).

[20]. Zar, J.H. (2001). Biostatistical Analysis. Printice -Hall, Englewood Cliffs, N.J

[21]. Yilmaz, F. (2009). The comparison of heavy metal concentrations (Cd, Cu, Mn and $\mathrm{Zn})$ in tissues of three economically important fish (Anguilla Anguilla, Mugil cephalus and Oreochromis niloticus) inhabiting Koycegic Lake -Mugla (Turkey). Turkish Journal of Science and Technology 4: 7-15

[22]. Anim-Gyampo M., Kumi M and Zango M.S. (2013). Heavy metals concentrations in some selected fish species in Tono Irrigation reservoir in Navrongo, Ghana. Journal of Environment and Earth Science. ISSN 2224 - 3216. Vol. 3 No. 1, 2013

[23]. Saeed, S.M. and Shaker, I. M. (2008). Assessment of heavy metals pollution in water and sediments and their effect on Oreochromis niloticus in the Northern delta Lakes, Egypt. $8^{\text {th }}$ International Symposium on Tilapia in Aquaculture, 2008.

[24]. Asgedom, A.G., Besta, M. B., Gebremedhin, Y.W. (2012). Bioaccumulation of Heavy Metals in Fishes of Hashenge Lake, Tigray, Northern Highlands of Ethiopia. American Journal of Chemistry 2012, 2(6): 326 - 334

[25]. Osman A.G.M. and Kloas W. (2010). Water quality and heavy metal monitoring in water, sediments and tissues of the African catfish Clarias gariepinus (Burchell, 1822) from the River Nile, Egypt. Journal of Environmental Protection, 2010, Vol. 1. 389 400 .

[26]. Anim, A. K., Ahialey, E.K., Duodu, G.O., Ackah, M. and Bentil N, O. (2011). Accumulation profile of heavy metals in fish samples from Nsawam, along the Densu River, Ghana. Res.J.Environ Earth Sci. 3: 56 - 60

[27]. WHO (2004). Guidelines for drinking Water Quality: Recommendations $3{ }^{\text {rd }}$ Edn. World Health Organization, Geneva, pp. 516

[28]. Bradi, B.H. (2005). Heavy metals in the environment. Interface Science and Technology, ed. Hubbard, A., Vol.6. Elsevier Academic Press: Neubrucke

[29]. Muiruri, J.M., Nyambaka, H. N. and Nawiri, M.P. (2013). Heavy metals in Water and tilapia fish fron Athi -Galana-Sabaki tributaries, Kenya. International Food Research Journal 20(2): 891 - 896 
[30]. Nwani, C. D., Nwachi, D.A., Okogwu, O.I, Ude, E.F and Odoh, G.E. (2010). Heavy metals in fish species from lotic freshwater ecosystem at Afikpo, Nigeria. Journal of Environmental Biology, 31(5) 595 - 601.

[31]. FAO (2003). Fisheries and aquaculture topics. Quality and Safety of fish and fish products. Topical fact Sheets. In: FAO Fisheries and Aquaculture department, Rome $2003-2012$.

[32]. Tole, M.P. and Shitsama, J.M. (2003). Concentrations of heavy metals in water, fish and sediments of the Winam Gulf, Lake Victoria, Kenya. In: Lake Victoria Fisheries: Status, biodiversity and Management, by M.van der Knaap and M. Munawar (Eds), 2003, Aquatic Ecosystem Health and Management.

[33]. ATSDR, Agency for Toxic Substances and Disease Registry (2000). Toxicological Profile for Chromium. Atlanta, GA: US Department of Health and Human Service, Public Health Service. 1600 Clinton Road N.E, E-29 Atlanta, Georgia 30333 (6-9): $95-$ 134

[34]. Akan, J.C., Abdulrahman, F.I., Sodipo,O.A., Ochanya.A.E. and Askira, Y.K.(2010): Heavy metals in sediments from river Ngada, Maiduguri Metropolis, Borno state, Nigeria. Journal of Environmental Chemistry and Ecotoxicology Vol. 2((9), pp.131-140

[35]. Rahman, M. M., Fikria, A.F., Kamaruzzaman, B.Y. and Wan Nik, W.B. (2012). Distribution of trace metals in pore water along Terengganu beach. Australian Journal of Basic and Applied Sciences, 6(7), 213 - 217

[36]. Ugwu, A.I., Wakawa, R. J., La'ah, E. and Olotu, A. (2012). Spatial distribution of heavy metals in river Usuma sediments and study of factors impacting the concentration. IJRRAS 12(2): $294-303$

[37]. WHO (2008). Guidelines for drinking water quality, World Health Organization, Geneva, 2008

[38]. Suresh, B., Steiner, W., Rydlo, M .and Taraschewski, H. (1999).Concentrations of 17 elements in Zebra mussel (Dreissena polymorpha). Environmental Toxicology and Chemistry, 18: $2574-9$

[39]. Krishna, P.V., Rao, K.M., Swaruparani, V and Rao, D.S. (2014). Heavy metal concentrations in Fish Mugil cephalus from Machilipatnam Coast and possible health risks to fish consumers. British Biotechnology Journal 4(2): 126 - 135.

[40]. FAO/WHO (1984). List of maximum levels recommended for contaminants by the joint FAO/WHO Codex Alimentarius Commission, $3: 1-8$

[41]. Makimilua, T.B. and Afua M. A. (2013). Determination of Selected Heavy metal and Iron Concentration in two common fish species in Densu River at Weija District in Grater Accra region of Ghana. American International Journal of Biology 1(1): 45 - 55.

[42]. Eneji, I. S., Ato, S.R. and Annune, P.A. (2011). Bioaccumulation of heavy metals in fish (Tilapia zilli and Clarias gariepinus) organs from River Benue, North- Central Nigeria. Pakistan J. Anal.Environ. Chem.Vol.12. No.1\&2 (2011) 25 - 31 